\title{
Pengaruh Model Pembelajaran Kooperatif Tipe TGT (Team Games Tournament) Terhadap Motivasi Belajar dan Pemahaman Konsep Matematika
}

\author{
Neneng Mila Avivah, Eko Fajar Suryaningrat \\ Institut Pendidikan Indonesia \\ milaavivah135@gmail.com
}

\section{Article History}

accepted 2/11/2019

approved 23/11/2019

published 31/12/2019

\begin{abstract}
Students are less motivated in learning and lack understanding of mathematical concepts. Researchers used the Team Games Tournament type of cooperative learning model to determine the effect on the learning process. quasi-experimental research, design nonequivalent control group design. Sampling with Purposive Sampling. The instruments used were questionnaires, tests and observations. The results of research data on student motivation after being given the Team Games Tournament model with t-test data analysis showed that tcount $=10.6$ and then used inferential statistics with a value $=2.073$. the reception area of $\mathrm{HO}$ is between $-2,073$ and 2,073. $\mathrm{HO}$ is rejected and $\mathrm{Ha}$ is accepted. While the results of the analysis of understanding of mathematical concepts with the t-test showed that tcount $=2.176$ and ttable $=2.015$ because tcount $=2.176>$ ttable $=2.015$ outside the reception area of $\mathrm{HO}$ then $\mathrm{HO}$ was rejected and Ha was accepted. there are significant differences in learning motivation and understanding of mathematical concepts of students who get the Team Games Tournament cooperative learning model and those who do not get the learning model.
\end{abstract}

Keywords: motivation to learn, understanding mathematical concepts, TGT

\section{Abstrak}

Siswa kurang termotivasi dalam belajar dan kurang paham terhadap konsep matematika. Peneliti menggunakan model pembelajaran kooperatif tipe Team Games Tournament untuk mengetahui pengaruh pada proses pembelajaran. penelitian kuasi eksperimen, desain nonequivalent control group design. pengambilan sampel dengan Purposive Sampling. Instrumen yang digunakan angket, tes, dan observasi. Hasil penelitian data motivasi belajar siswa setelah diberikan model Team Games Tournament dengan analisis data uji-t' menunjukkan bahwa t' ${ }^{\prime i t u n g}=10,6$ dan selanjutnya digunakan statistik inferensial dengan nilai $=$ 2,073. daerah penerimaan $\mathrm{H}_{0}$ berada diantara $-2,073$ dan 2,073. $\mathrm{H}_{0}$ ditolak dan $\mathrm{Ha}$ diterima. Sedangkan hasil analisis pemahaman konsep matematika dengan uji-t menunjukkan bahwa thitung $=2,176$ dan tabel $=2,015$ karena thitung $=2,176>$ tabel $=2,015$ di luar daerah penerimaan $\mathrm{H}_{0}$ maka $\mathrm{H}_{0}$ ditolak dan $\mathrm{Ha}$ diterima. terdapat perbedaan siginifikan motivasi belajar dan pemahaman konsep matematika siswa yang mendapatkan model pembelajaran kooperatif tipe Team Games Tournament dan yang tidak mendapatkan model pembelajaran.

Kata kunci: motivasi belajar, pemahaman konsep matematika, TGT

Social, Humanities, and Education Studies (SHEs): Conference Series https://jurnal.uns.ac.id/shes

p-ISSN 2620-9284

e-ISSN 2620-9292 


\section{PENDAHULUAN}

Matematika dianggap sebagai mata pelajaran yang membosankan hal ini terlihat dari masih banyaknya siswa yang berbincang-bincang saat guru menjelaskan materi. Siswa cenderung bosan karena pembelajaran belum mengandung unsur permainan. Siswa belum diberi kesempatan untuk mengemukakan pendapatnya karena pembelajaran berpusat pada guru. Siswa kurang antusias mengikuti pembelajaran karena asyik dengan mainan yang dimilikinya. Hasil matematika pun rendah. (Darmayanti, 2017, hlm. 4).

Permasalahan di atas diharapkan dapat diatasi dengan salah satu cara yaitu guru mengkolaborasikan antara model pembelajaran yang biasa digunakan dengan model pembelajaran yang mampu meningkatkan motivasi siswa. Guru menggunakan teknik pembelajaran menciptakan suasana pembelajaran yang aktif dan menyenangkan sehingga partisipasi belajar siswa meningkat. Serta menggunakan pendekatan yang efektif untuk menyajikan tema-tema matematika yang atraktif.

Mengingat fakta tersebut harus di akui bahwa pada umumnya mata pelajaran matematika merupakan pelajaran yang sulit dipahami sehingga tidak sedikit siswa yang takut pada pelajaran matematika, selain itu matematika dianggap pelajaran yang sangat membosankan. Dengan keadaan yang demikian dan juga kurang semangatnya siswa mengakibatkan hasil belajar matematika yang rendah.

Hal penting bukan hanya motivasi belajar siswa namun juga dengan pemahaman konsep siswa. Pemahaman konsep sangat penting dalam pembelajaran matematika, karena dengan pemahaman yang matang maka siswa dapat memecahkan suatu masalah dan mampu mengaplikasikan pembelajaran tersebut pada dunia nyata. Hal ini sesuai dengan pernyataan Nikmah (2016, hlm. 11) yang menyatakan bahwa "pemahaman konsep merupakan salah satu hal yang penting dalam pembelajaran, terutama dalam pembelajaran matematika".

Berdasarkan hasil observasi awal dan wawancara dari guru kelas IV SDN 2 Mekarsari bahwa pada umumnya disekolah tersebut pembelajaran dengan metode ceramah dan pemberian tugas mandiri. Metode ini tidak dapat mengatasi masalah pemahaman konsep siswa. Meskipun sudah dilakukan berbagai cara untuk meningkatkan pemahaman konsep siswa, seperti diadakannya remedial bagi siswa yang nilainya tidak mencapai standar ketuntasan dan memberi tugas pengembangan materi berupa soal. Tetapi belum bisa mengatasi masalah pemahaman konsep siswa.

Japa (2012, hlm. 2) menyatakan bahwa "dalam pembelajaran matematika, guru harus dapat menciptakan suasana lingkungan yang memungkinkan seseorang (si pelajar) melaksanakan kegiatan belajar matematika". Hal ini berarti pembelajaran harus berpusat pada siswa dan pembelajaran harus menyenangkan.

Model pembelajaran Teams Games Tournament (TGT) sangat sesuai dengan karakteristik pembelajaran matematika, karena dalam pembelajaran matematika, siswa sering dihadapkan pada latihan-latihan soal atau pemecahan masalah. Bagi siswa tertentu, bertanya kepada teman sebaya untuk mendapatkan penjelasan terhadap apa yang telah dijelaskan oleh guru akan lebih mudah dipahami oleh siswa karena mereka biasanya menggunakan bahasa dan ungkapan yang biasa digunakan oleh anak sebaya dan secara psikologis mereka dalam berkomunikasi tidak ada beban (Darmayanti, Vol 4).

Menurut Rusman (2011, hlm. 224) "model pembelajaran TGT merupakan model pembelajaran kooperatif dengan membentuk kelompok-kelompok kecil dalam kelas yang terdiri atas 3-5 siswa yang heterogen, baik dalam hal akademik, jenis kelamin, ras, maupun etnis". Pembelajaran kooperatif model TGT adalah salah satu tipe model pembelajaran kooperatif yang mudah diterapkan, melibatkan aktiitas seluruh siswa tanpa harus ada perbedaan status, melibatkan peran siswa sebagai tutor sebaya dan mengandung unsur permainan dan reinforcement. 
Berdasarkan uraian latar belakang di atas, maka peneliti terdorong untuk melakukan penelitian yang dapat memotivasi belajar serta memahami konsep matematika di salah satu sekolah melalui Model Pembelajaran TGT dengan judul penelitian Pengaruh Model Pembelajaran Kooperatif Tipe TGT (Team Games Tournament) Terhadap Motivasi Belajar dan Pemahaman Konsep Matematika.

Berdasarkan latar belakang yang telah dipaparkan, maka peneliti dapat merumuskan permasalahan penelitian, yakni:

1. Bagaimana penerapan model pembelajaran TGT (Teams Games Tournament) terhadap motivasi belajar dan pemahaman konsep matematika siswa?

2. Apakah ada perbedaan motivasi belajara siswa dan pemahaman konsep matematika siswa yang mendapatkan model pembelajaran kooperatif tipe TGT (Teams Games Tournament) dengan yang tidak mendapatkan model pembelajaran?

3. Apakah model pembelajaran kooperatif tipe TGT (Teams Games Tournament) berpengaruh terhadap motivasi belajar dan pemahaman konsep matematika pada kelas IV Sekolah Dasar Negeri 02 Mekarsari?

\section{METODE}

Metode penelitian ini menggunakan Kuasi Eksperimen. Sugiyono (2013, hlm. 114) menjelaskan bahwa "desain ini mempunyai kelompok kontrol, tetapi tidak dapat berfungsi sepenuhnya untuk mengontrol variabel-variabel luar yang mempengaruhi pelaksanaan eksperimen". Adapun desain penelitian yang menggunakan desain penelitian Non-Equivalent Control Grup Design. Populasi penelitian ini adalah seluruh siswa kelas IV SDN 2 Mekarsari tahun pelajaran 2019/2020. Sedangkan sampel penelitian ini dilakukan penarikan sampel di kelas IV dengan jumlah siswa 46 orang, 23 orang kelas eksperimen dan 23 orang kelas kontrol. Teknik pengambilan sampel diambil dengan Purposive Sampling yaitu teknik penentuan sampel dengan pertimbangan tertentu, (Sugiono, 2015, hlm. 85). Instrumen yang digunakan dalam penelitian ini adalah tes dan angket. Tes untuk mengukur pemahaman konsep siswa dengan jumlah soal 10 butir berupa esay dan lembar angket untuk melihat motivasi belajar siswa.

\section{Hasil Penelitian}

\section{HASIL DAN PEMBAHASAN}

Berikut merupakan gambaran dari penerapan model TGT (Team Games Tournament) dari pertemuan 1-3 berdasarkan observasi peneliti di kelas Eksperimen.

Tabel 1

Data Hasil Penelitian Motivasi Belajar

\begin{tabular}{|c|c|c|c|c|}
\hline \multirow{2}{*}{ Keterangan } & \multicolumn{2}{|c|}{ Kelompok Kontrol } & \multicolumn{2}{c|}{$\begin{array}{c}\text { Kelompok } \\
\text { Eksperimen }\end{array}$} \\
\cline { 2 - 5 } & $\begin{array}{c}\text { Tes } \\
\text { Awal }\end{array}$ & Tes akhir & Tes awal & Tes Akhir \\
\hline Jumlah siswa & 23 & 23 & 25 & 23 \\
\hline Nilai terbesar & 84,7 & 81,22 & 68 & 82,9 \\
\hline Nilai terkecil & 64,8 & 60,84 & 57 & 75 \\
\hline Rata-rata & 75,6 & 65,92 & 62,54 & 79,71 \\
\hline Simpangan baku & 5,19 & 6,094 & 2,83 & 2,097 \\
\hline
\end{tabular}

Tabel 2 
4th National Seminar on Guidance and Counseling (SNBK 2019) and Workshop on

Pedagogical Theory and Practice (WTPP 2019)

SHEs: Conference Series 2 (2) (2019) $171-177$

Data Hasil Pemahaman Konsep

\begin{tabular}{|c|c|c|c|c|}
\hline \multirow{2}{*}{ Keterangan } & \multicolumn{2}{|c|}{ Kelompok Kontrol } & \multicolumn{2}{c|}{$\begin{array}{c}\text { Kelompok } \\
\text { Eksperimen }\end{array}$} \\
\cline { 2 - 5 } & Tes Awal & Tes akhir & Tes awal & $\begin{array}{c}\text { Tes } \\
\text { Akhir }\end{array}$ \\
\hline Jumlah siswa & 23 & 23 & 25 & 23 \\
\hline Nilai terbesar & 77 & 70 & 64 & 77 \\
\hline Nilai terkecil & 17 & 20 & 18 & 23 \\
\hline Rata-rata & 44,42 & 42,94 & 38,22 & 52,5 \\
\hline Simpangan baku & 18,67 & 15,23 & 13,00 & 14,73 \\
\hline
\end{tabular}

Penelitian ini dilaksanakan di SDN 2 Mekarsari, Garut. Dari seluruh kelas IV diambil sampel dua kelas yaitu kelas IV-B sebagai kelompok Eksperimen dengan diberikan perlakuan menggunakan model pembelajaran Kooperatif tipe TGT (Team Game Tournament) dan kelas IV-A sebagai kelas kontrol tanpa meggunakan perlakuan. Banyak subjek penelitian pada kelas kontrol sebanyak 23 siswa dan pada kelompok eksperimen sebanyak 23 siswa. Kedua kelas tersebut diberikan pretest dan posttest, diperoleh hasil sebagai berikut:

Berdasarkan analisis hasil pretes motivasi belajar t' $=57,15$ dan karena tidak berdistribusi normal maka selanjutnya digunakan statistik inferensial dengan nilai $=$ 2,073. Sehingga daerah penerimaan $\mathrm{H}_{0}$ berada diantara $-2,073$ dan 2,073 . Karena $\mathrm{t}^{\prime}$ berada di luar daerah penerimaan $\mathrm{H}_{0}$ maka $\mathrm{H}_{0}$ ditolak dan $\mathrm{Ha}$ diterima.

Sedangkan analisis data hasil posttest t' $=10,42$ dan dan karena tidak berdistribusi normal maka selanjutnya digunakan statistik inferensial dengan nilai $=$ 2,074. Sehingga daerah penerimaan $\mathrm{H}_{0}$ berada diantara $-2,073$ dan 2,073 . Karena $\mathrm{t}^{\prime}$ berada di luar daerah penerimaan $\mathrm{H}_{0}$ maka $\mathrm{H}_{0}$ ditolak dan $\mathrm{Ha}$ diterima, maka hipotesis penulis diterima yaitu "terdapat perbedaan yang signifikan terhadap pemahaman konsep siswa kelas eksperimen dan siswa kelas kontrol". Maka dengan kata lain model pembelajaran Kooperatif tipe TGT (Team Game Tournament) berpengaruh terhadap motivasi belajar siswa.

Dalam penelitian ini selain menggunakan uji t' dilakukan juga uji gain untuk melihat peningkatan motivasi belajar siswa, dan dapat dilihat peningkatan rata-rata kelas eksperiman dan kontrol pada tabel dibawah ini.

Tabel 3

Data Gain Ternormalisasi

\begin{tabular}{|c|c|c|c|c|c|}
\hline Kelompok & $\begin{array}{c}\text { Jumlah } \\
\text { siswa }\end{array}$ & $\begin{array}{c}\text { Skor } \\
\text { terkecil }\end{array}$ & $\begin{array}{c}\text { Skor } \\
\text { terbesar }\end{array}$ & Gain & Interpretasi \\
\hline Eksperimen & 23 & 0,31 & 0,56 & 0,47 & Sedang \\
\hline Kontrol & 23 & $-0,54$ & 0,19 & - & $\begin{array}{c}\text { Terjadi } \\
\text { penurunan }\end{array}$ \\
\hline
\end{tabular}

Dari tabel di atas menjeleaskan bahwa terjadi peningkatan motivasi belajar siswa di kelas ekseperimen.

Sedangkan berdasarkan analisis hasil pretest pemahaman konsep, t' $=1,306$ dan karena tidak berdistribusi normal maka selanjutnya digunakan statistik inferensial dengan nilai $=2,0738$. Sehingga daerah penerimaan $\mathrm{H}_{0}$ berada diantara $-2,0738$ dan 2,0738. Karena t' berada didaerah penerimaan $\mathrm{H}_{0}$ maka $\mathrm{Ha}$ ditolak dan $\mathrm{H}_{0}$ diterima. 
Ssedangkan analisis data hasil posttest pemahaman konsep, $t_{\text {hitung }}=2,176$ dan $t_{\text {tabel }}=2,015$. Sehingga daerah penerimaan $\mathrm{H}_{0}$ tidak berada diantara $-2,176$ dan 2,176. Karena thitung tidak berada didaerah penerimaan $\mathrm{H}_{0}$ maka $\mathrm{Ha}$ diterima dan $\mathrm{H}_{0}$ ditolak.

Dengan demikian dapat disimpulkan bahwa data hasil tes akhir dari kedua kelompok tersebut menyatakan $\mathrm{H}_{0}$ ditolak, dan $\mathrm{Ha}$ diterima, dengan kata lain terdapat perbedaan yang signifikan kemampuan pemahaman konsep antara siswa kelompok kontrol dan kelompok eksperimen.

Selain menggunakan uji t dilakukan juga uji gain untuk melihat peningkatan motivasi belajar siswa, dan dapat dilihat peningkatan rata-rata kelas eksperiman dan kontrol pada tabel dibawah ini.

Tabel 4

Deskripsi Data Gain Ternormalisasi

\begin{tabular}{|c|c|c|c|c|c|}
\hline kelompok & $\begin{array}{c}\text { Jumlah } \\
\text { siswa }\end{array}$ & $\begin{array}{c}\text { Skor } \\
\text { terkecil }\end{array}$ & $\begin{array}{c}\text { Skor } \\
\text { terbesar }\end{array}$ & Gain & interpretasi \\
\hline Eksperimen & 23 & 0,06 & 0,60 & 0,36 & Sedang \\
\hline Kontrol & 23 & $-0,71$ & 0,46 & 0,00 & Tetap \\
\hline
\end{tabular}

Dari tabel di atas menjeleaskan bahwa terjadi peningkatan motivasi belajar siswa di kelas ekseperimen.

\section{Pembahasan}

Berdasarkan hasil tes dan angket yang dilakukan sebanyak tiga kali pertemuan menunjukkan bahwa kelas yang menggunakan mode pembelajar TGT (Team Game Tournament) lebih baik dengan yang tidak menggunakan model. Artinya langkahlangkah dalam model pembelajaran Kooperatif tipe TGT (Team Game Tournament), berhasil pendidik terapkan dengan sangat baik, karna model pembelajaran Kooperatif tipe TGT (Team Game Tournament) ini sangat cocok diterapkan di SD.

Penerapan pembelajaran model kooperatif tipe TGT (Team Game Tournament) pada mata pelajaran matematika terdapat pengaruh yang positif terhadap motivasi belajar siswa semua itu dapat dilihat dari perbedaan aktivitas yang sangan menonjol dari kedua kelas tersebut yang dimana kelas eksperimen KBM melibatkan siswa dengan menggunakan model pembelajarn kooperatif tipe TGT (Team Game Tournament) sedangkan pada kelas kontrol menggunakan ceramah bervariasi.

Berdasarkan hasil analisis terlihat jelas bahwa nilai rata-rata skor kelas eksperimen yang dibelajarkan dengan menggunakan model TGT (Team Game Tournament) lebih baik jika dibandingkan dengan kelas kontrol yang hanya dibelajarkan secara konvensional, pada pertemuan pertama, kedua, dan ketiga, dengan kata lain model TGT (Team Game Tournament) berpengaruh terhadap motivasi belajar dan pemahaman konsep siswa.

Berdasarkan rata-rata nilai posttest kedua kelas, terlihat bahwa rata-rata nilai posttest kelas eksperimen lebih tinggi dibandingkan rata-rata nilai posttest kelas kontrol dengan menggunakan uji t untuk membuktikan apakah ada pengaruh yang signifikan. Dengan menggunakan taraf signifikansi $5 \%$ atau $=0,05$ berdasarkan uji $t_{\text {hitung }}=2,176$ sedangkan nilai $t_{\text {tabel }}$ dengan taraf signifikansi $5 \%$ adalah 2,015. Dengan kata lain thitung berada didaerah penolakan $\mathrm{H}_{0}$ dan $\mathrm{Ha}$ diterima Hal ini menunjukkan bahwa terdapat perbedaan kemampuan pemahaman konsep antara siswa kelompok kontrol dan kelompok eksperimen. Selain menggunakan uji $t$ peneliti juga menggunakan uji $\mathrm{N}$-Gain untuk melihat peningkatan pemahaman konsep siswa diperoleh hasil rata-rata Gain untuk kelas eksperimen 0,60 sedangkan pada kelas kontrol 0.46, dimana rata-rata nilai Gain kelas eksperimen lebih besar dari kelas kontrol. berdasarkan hasil uji t dan dilihat juga dari peningkatan belajar bahwa model 
pembelajaran TGT (Team Game Tournament) mempunyai pengaruh yang lebih besar dibandingkan dengan kelas kontrol yang tidak mendapatkan model TGT (Team Game Tournament).

Pada penelitian yang dilakukan terlihat bahwa siswa pada kelas eksperimen yang diajar dengan model pembelajar TGT (Team Game Tournament) lebih meningkat dari nilai pretest sebelumnya terlihat dari nilai rata-rata pemahman konsep, dengan kata lain siswa termotivasi untuk belajar. Perhatian siswa juga lebih fokus sehingga lebih mudah konsentrasi dalam menerima pelajaran.

Dengan model ini maka guru memberikan kesempatan kepada siswa untuk aktif belajar bersama tanpa membeda-bedakan, menumbuhkan rasa kebersamaan dan tanggung jawab, siswa bersemangat dan senang ketika pembelajaran berlangsung. Hal ini sesuai dengan kelebihan dari model TGT (Team Game Tournament) yang di ungkapkan oleh Shoimin (2014:207), sebagai berikut:

a. Model TGT (Team Games Tournament) melibatkan siswa ikut aktif dan mempunyai peranan penting dalam kelompoknya.

b. Menumbuhkan rasa kebersamaan dan saling menghargai sesama anggota timnya.

c. Membuat peserta didik lebih bersemangat dalam mengkuti pembelajaran.

d. Membuat peserta didik menjadi lebih senang dalam mengikuti pelajaran.

Berdasarkan pemaparan diatas, dapat disimpulkan bahwa penggunaan model pembelajaran TGT (Team Game Tournament) berpengaruh signifikan terhadap motivasi belajar dan pemahaman konsep matematika.

\section{SIMPULAN}

Berdasarkan hasil penelitian dan pembahasan, maka beberapa simpulan penelitian ini adalah:

1. Penerapan model pembelajaran kooperatif tipe TGT (Team Games Tounament) dapat meningkatkan motivasi belajar dan pemahaman konsep matematika.

2. Terdapat perbedaan motivasi belajar siswa dan pemahaman konsep matematika antara siswa yang mendapatkan model pembelajaran kooperatif tipe TGT (Team Games Tounament) dengan yang tidak mendapatkan model pembelajaran.

3. Model pembelajaran kooperatif tipe TGT (Team Games Tounament) mempengaruhi motivasi belajar dan pemahaman konsep matematika.

\section{DAFTAR PUSTAKA}

Ambarjaya, S. Beni. (2008). Model-model pembelajaran kreatif. Bandung: TINTA EMAS Publishing.

Billah, Fairuzabadi Arif. (2017). "Pengaruh Model Pembelajaran Kooperatif Teams Games Tournament (TGT) terhadap Minat Belajar IPS Siswa Kelas IV SD Muhammadiyah 12 Pamulang". Fakultas IImu Tarbiyah dan Keguruan. UIN Syarif Hidayatullah. Jakarta.

Darmayanti. (2012). Pengaruh Model TGT terhadap Hasil Belajar Matematika dengan Kovariabel Kemampuan Numerik pada Siswa Kelas V. e-journal PGSD Pendidikan Ganesha. (4)

Kementrian Pendidikan dan Kebudayaan RI. (2011). Peraturan Mendiknas tentang Satuan Pengawasan Internal (Permendiknas Nomor 47 tahun 2011). Jakarta: Penulis.

Nikmah, Nur Sholekhatun. \& Masduki. (2016). Penggunaan Peta Konsep dalam Penilaian Pemahaman Konsep Lingkaran. Makalah disajikan dalam Prosiding di Universitas Muhammadiyah Surakarta. 12 Maret 2016. 
4th National Seminar on Guidance and Counseling (SNBK 2019) and Workshop on

Pedagogical Theory and Practice (WTPP 2019)

SHEs: Conference Series 2 (2) (2019) $171-177$

Rakhmat, Cece,. Budiman, Nandang,. dan Herawati, Nenden Ineu. (2006). Psikologi Pendidikan. Bandung: UPI PRESS.

Shoimin, A. (2014). 68 Model Pembelajaran Inovatif dalam Kurikulum 2013. Yogyakarta: Ar-Ruzz Media.

Sugiono. (2013). Metodologi Penelitian Kuantitatif, Kualitatif, dan R\&D. Bandung: Alfabeta.

Uno dan Mohamad. (2014). Belajar dengan Pendekatan Paikem. jakarta : Rosda Karya

Uno. B. Hamzah. (2009). Teori Motivasi dan Pengukurannya Analisis di Bidang Pendidikan. Jakarta: PT Bumi Aksara. 